\title{
A fundamental relação entre os âmbitos doméstico e público na habitação social
}

The fundamental relationship between domestic and public spheres in social housing

La relación fundamental entre las esferas doméstica y pública en la vivienda social

\author{
NUNES, Orlando Vinicius Rangel ${ }^{1}$ \\ GUINANCIO, Cristiane ${ }^{2}$ \\ 1 Department of Architecture and Urbanism, Centro Universitário IESB, Brasília, DF, Brazil. \\ orlandovrnunes@gmail.com \\ ORCID ID: 0000-0002-2771-3786 \\ 2 Postgraduate Program in Architecture and Urbanism, Faculty of Architecture and Urbanism, \\ Universidade de Brasília, Brasília, Brazil. \\ cristiane-g@uol.com.br \\ ORCID ID: 0000-0002-1575-1064
}




\title{
Resumo
}

A necessidade de condições adequadas de vida para a população, particularmente para os que vivem em áreas de vulnerabilidade social, é tema recorrente na literatura das ciências sociais aplicadas. Fatores como deficiência nas infraestruturas e nos serviços, exclusão do mercado imobiliário formal, segregação socioespacial e condições precárias de salubridade caracterizam esses territórios. A insegurança e hostilidade existentes tem resultado no afastamento da população dos espaços públicos e as residências se fecham para o exterior. Nesse contexto, o artigo tem como objetivo apontar a necessidade da relação entre os âmbitos doméstico e público como aspecto fundamental para a realização da vida dessas famílias. Para isso utiliza-se o método da pesquisa-ação, referenciando-se no percurso histórico da Habitação Social no Brasil e em conceitos e reflexões consolidadas, para aplicação em estudo de caso no Distrito Federal, Brasil. Os resultados alcançados evidenciaram a contribuição do resgate das conexões interior-exterior das moradias para a qualificação das condições de vida da população em situação de vulnerabilidade social.

Palavras-Chave: habitação de interesse social, âmbitos doméstico e público, modos de vida.

\begin{abstract}
The need for the population to have adequate living conditions, particularly those living in areas of social vulnerability, is a recurring theme in the literature of applied social sciences. These territories are characterized by factors such as deficiencies in infrastructure and services, exclusion from the formal real estate market, socio-spatial segregation and precarious health conditions. Prevailing insecurity and hostility has resulted in the population moving away from public spaces, and homes have been closed towards the outside. Within this context, the aim of this article is to demonstrate how the relationship is necessary between the domestic and public spheres as a fundamental aspect for these families to be able to realize their lives. Thus, the action research method has been used, referencing the historical course of social housing in Brazil and the consolidated concepts and reflections, in order to apply them to a case study in the Federal District, Brazil. The achieved results demonstrated the contribution of the interior-exterior connections of homes in qualifying the living conditions of socially vulnerable populations.
\end{abstract}

Key-Words: Social Housing, Domestic and Public Spheres, Ways of Life.

\section{Resumen}

La necesidad de condiciones de vida adecuadas para la población, particularmente para quienes viven en áreas de vulnerabilidad social, es un tema recurrente en la literatura de las ciencias sociales aplicadas. Factores como la deficiencia en infraestructura y servicios, la exclusión del mercado inmobiliario formal, la segregación socioespacial y las precarias condiciones de salud caracterizan a estos territorios. La inseguridad y hostilidad existente ha provocado que la población se aleje de los espacios públicos y las residencias se cierren al exterior. En este contexto, el artículo tiene como objetivo señalar la necesidad de la relación entre el ámbito doméstico y público como aspecto fundamental para la realización de la vida de estas familias. Para eso, se utiliza el método de investigación participante, referido a la trayectoria histórica de la Vivienda Social en Brasil y a conceptos y reflexiones consolidados, para su aplicación en un estudio de caso en el Distrito Federal, Brasil. Los resultados alcanzados mostraron el aporte del rescate de las conexiones interioresexteriores de las viviendas para la calificación de las condiciones de vida de la población en situación de vulnerabilidad social.

Palabras clave: vivienda social, esferas domésticas y públicas, formas de vida. 


\section{Introduction}

Within the scope of social housing - SH, constitutional rights to health, housing and the city have been compromised in the face of urban socio-spatial segregation, stifled infrastructure and environmental degradation. Socially vulnerable families are exposed to precarious, unsanitary and overcrowded conditions in their homes, which increases their vulnerability to contamination, particularly in the current pandemic context of COVID-19. The inadequacy of the physical conditions is further heightened due to the hostility and aggressiveness inherent in the urban context, in view of the ruptures that have become established in the connections between domestic and public spheres, through having to close up the frontages of their homes for security reasons. This threshold is configured as an intermediate zone that materializes the tensions in space resulting from forces of a social, economic and political nature.

In this article, the domestic and public spheres refer to an understanding that life is realized through a set of human activities that characterize family and social dynamics. It encompasses basic daily needs and the respective social interactions, considering that the lives of families are not limited to the home, but involve the satisfaction of collective living in the urban space. Thus, the reflection is based on the understanding of "dwelling", which is undertaken in both the practical and symbolic dimensions (REIS CABRITA, 1995; CORREA, 2007; PEREIRA, 2012; COELHO, 2012). This orientation leads to the necessary connection between the interior and the exterior of the house, thereby enabling a relationship between the domestic and public spheres.

It is understood that housing is conceived as a process, allowing a continuous adaptation to the needs of families (BLUMENSCHEIN et al., 2015). In the scope of housing, it is considered that meeting present needs and meeting future expectations may enable a greater degree of adaptation to the needs of residents. within the context of the external space, it is understood that collective experience complements the life of both the family and the individual. The neighborhood and the district act as an extension of the home.

This theme has been investigated from various perspectives, of which the most prominent recent research has been on: spatial configuration (SUN; PONT; LEGEBY, 2017; TOPRAK; ÜNL; NES, 2019; ZEROUATI; BELLAL, 2020) and urban design (DE PAOLI), 2014; MÜLLER; TRUBINA, 2020; CIANCIOTTO, 2020). As illustrated by Furlan and Duda (2019), few articles have sought to investigate simultaneously Technical Assistance for Social Housing - ATHIS, and the relationship between the domestic and public spheres.

Within this context, the aim of this article is to demonstrate how the relationship is necessary between the domestic and public spheres as fundamental aspect for the realization of life within the urban environment. For this, support is obtained from established understandings in the literature, with reference to the historical course of $\mathrm{SH}$ and observing the relationships between the domestic and public spheres. It should be noted that although this theme is frequently found in studies and research, the understanding of this link has rarely been explored. The research object is the urban improvement action undertaken in a structural city square, in the Federal District of Brazil, which enabled: (1) the collection of data on the conditions of the historical formation of the territory and the social relations inherent to it; and (2) the application of the main concepts observed in the literature.

The methodological procedures were guided by the action research method, as it is based on a qualitative assessment of social manifestations and is linked to interventions (GORI, 2006), with objectives that are aligned with the urban action undertaken. According to Thiollent (2000), action research assumes an instrumental objective insofar as it aims to solve a practical, technical problem; contributes to collective awareness, in order to develop awareness on local problems; and is oriented towards the production of knowledge, which is not restricted to the collectivity considered in the investigation.

Action research adopts participatory planning as a methodological strategy (DEMO, 1995), which is developed over three moments: (i) self-diagnosis establishes the confluence between scientific and popular knowledge (knowledge, accumulation and systematization of data); (ii) the construction of a practical coping strategy enables the identification of problems and the establishment of priorities based on systematized knowledge (proving the capacity of the community to build a common project); and (iii) 
the third moment demonstrates the need for organization in order to face problems.

The approach begins with an historical synthesis of $\mathrm{SH}$ production in Brazil as from the twentieth century. Larger-scale public policies and programs are considered, observing the conjuncture in which they were undertaken. It should be noted that, after the 1960s, for the most part, these policies favored the construction of housing focusing on quantity rather than quality. As a result of inadequacies for the needs of families, interventions carried out in housing units have generated tension between the domestic and public spheres.

The following section presents the concepts and reflections by authors who have dwelt on this reflection, which have then been applied to a case study. The conditions for planning and implementing urban action in a square are also presented, focusing on the relationship between the domestic and public spheres, and seeking to characterize the (inter)related "dwelling", as well as the physical elements that characterize this interface such as outside walls, sidewalk and openings.

The reflections have demonstrated the significant implication of historical and macro-social structures in compromising the daily life of the least favored members of the population. On the other hand, the implemented urban action contributed to qualifying the conditions of "dwelling" by transforming the interior-exterior relationship of the dwelling, changing it from a context in which families had become isolated from the public space, to a condition in which they began to relate with one another through physical elements of accessibility and communicability. These aspects reveal how the connections between the domestic and public spheres are fundamental, and establish adequate conditions by which "dwelling" may be realized in areas of social vulnerability.

\section{The context of social housing in Brazil and the relationship between the public and domestic spheres}

In the late nineteenth and early twentieth centuries, during the transition from an agricultural economy to the beginning of industrialization, Brazilian cities experienced a rapid population increase. Space restrictions largely affected the most disadvantaged. The consequences of this process were a housing shortage and serious health problems (OLIVEIRA, 1971). Throughout the twentieth century, different forms of assistance were implemented through institutional initiatives or self-management aimed at different income groups. Quantitatively significant solutions were adopted, although with a limited outreach in view of the proportions of demand.

From the first decade of the twentieth century, an increasing role was played by industrialists, public institutions, railway companies and construction companies in the production of housing (CORREIA, 2004). The interventions promoted the valorization of urban plots and the consequent socio-spatial segregation. The exclusion of the poorer population from urbanized centers and the continuous increase in the housing demand determined the need for greater action by the State.

In the 1930s, government actions in the production of housing units began to be observed, with priority given to the working class. The discussions and proposed solutions were influenced by the concept of minimum housing from the International Congress of Modern Architecture - CIAM of 1929. Modernist principles were adapted to the government's national-developmental project. According to Bonduki (1998) and Bonduki and Koury $(2014$, v. 1), the modernist-inspired housing nuclei were spaces that favored the objectives of order, control, subordination and massification, which integrated the political and ideological project of the Estado Novo'.

The experience of the Institutes of Retirement and Pensions ${ }^{2}$ - IAPs appropriated the ideal of rationalized construction in responses directed towards specific groups. The solutions signposted a diversity in urban and architectural terms, and in construction technologies (BONDUKI, 2014). Proposals were developed for the construction and for the internal arrangement of the house, implying changes in domestic tasks through rationalization and the provision of collective structures for carrying it out. Community life was given value and social services were created as part of the debate agenda

\footnotetext{
${ }^{1}$ This was a political regime installed by President Getúlio Vargas in November 1937, and continued until January, 1946.

2 The Industrialist IAPs (IAPI), with operations characterized by the implementation of projects in central areas or in privileged locations of the city, was the most appropriated urban and architectural proposals of the Modern Movement with vertical residential buildings. By contrast, in the solutions for the trades people IAPS (IAPC), isolated houses in traditional lots predominated.
} 
on working class housing.

In the 1940s and 1950s, the implementation of SH in peripheral regions established precarious living conditions, since its implementation was proposed "not as a positive action, but as an excuse, which justified the acceptance of any type of housing settlement, irrespective of how precarious and unsanitary it was, since it was the only way to really face the lack of housing "(BONDUKI, 1994, p. $730)^{3}$.

The housing crisis resulting from a context of intense urbanization and increased demand led to the creation, in 1964, of the National Housing Bank - BNH. Urbanistic models were adopted as a way of consolidating a modernization project. The solutions were steered by modernist principles, although, to a large extent, guided by simplification. With priority given to producing the highest number of dwellings with an optimization of time and cost, these developments were characterized as large standardized housing complexes, built in the peripheral areas of cities and with repeated architectural solutions. In view of the inadequacy of the houses, their owners sought to adapt them to their own needs with interventions that generated tension between the domestic and public spheres. A scenario that was also reproduced in urban fractions of irregular occupation.

Throughout this historical process, the relationship between the domestic and public spheres has taken on different configurations. In the corridor streets of pre-industrial cities, this communication took place through the doors and windows of the facades, whereby the streets were considered a continuity of the rooms. In the tenements, collective activities were conducted in a circulation space surrounded by houses. These relationships, however, underwent decisive changes with the gradual appropriation of modernist references for the formal production of SH. Many of the street functions were diminished or even disappeared in solutions where buildings were distributed across wide open spaces of little use and in which, often, the visual integration was compromised by "blind" wall extensions with no windows (COELHO, 2012). The resulting new dynamic of urban life was also reflected in the lives of the families, which resulted in a reduction of public life experience.

As part of the critique against modernist principles in the 1960s, the contribution brought by traditional spatial arrangements was once again taken up, with human-related spatial scales being reclaimed: home, street, neighborhood and city. Reflection began with the relationship between the house and the street, highlighting a "third sphere" (SILVA, 2012), which was established in the intermediate space between public and private. This sphere has the potential for conflicts and links, where, in the context of $\mathrm{SH}$, the negative impacts resulting from interventions brought about by residents are evident.

During this period, criticism of "orthodox" modernist urbanism, which was assumed to be mostly functionalist, became more apparent outside Brazil ${ }^{4}$. The work that reinforced this criticism was launched in 1961, by the journalist and political activist Jane Jacobs, in her book The Death and Life of Great American Cities, which in Brazil was entitled Morte e Vida de Grandes Cidades, and published in 2000. It was based on a critique of the hegemonic functionalist urbanism of the time, which had been disseminated by the Athens Charter for the purpose of reconstructing cities during the post-war period.

One of the impacts of the work was the importance attributed to streets within the urban fabric, and the role of sidewalks. This theme was especially relevant at the time due to proposals for segregating flows and uses that governed functionalist urbanism with modernist roots. Within this debate, Jacobs coined the term "eyes on the street", referring to the casual, natural surveillance that takes place between residents and pedestrians (WENDT, 2009). When addressing this concept, she stated that "[...] public peace [...] is not kept primarily by the police, necessary as police are. It is kept primarily by an intricate, almost unconscious network of voluntary controls and standards among the people themselves and enforced by the people themselves" (JACOBS, 1961, pp. 31-32).

Based on this observation, Jacobs makes a number of assumptions for urban design, which are in line with the interpretation of this article with regard to the relationship between domestic and public spheres. In a list of three characteristics, Jacobs indicated the need to pay attention to the "eyes on the street" of the natural users. In this regard, the buildings fulfill an important objective in preparing the streets to receive strangers and to ensure the safety of both themselves and the residents. Therefore,

\footnotetext{
${ }^{3}$ This and all non-English citations hereafter have been translated by the authors.

${ }^{4}$ Concomitantly, the situationists had criticized functionalist urbanism (Jacques, 2003). In this article, the approach by Jacobs (1961) has been emphasized since it approximates the object of research
} 
to attract these strangers, there should be reasons for displacement, involving establishments and other public places located along the sidewalks (JACOBS, 1961).

Based on Jacobs' (1961) thoughts, other studies over the decades have been conducted, either expanding or reaffirming the original concepts. Towards the end of the decade, in 1968, William Whyte wrote about sociability in urban spaces and highlighted a group of people he termed "undesirable", presenting them as teenagers, the homeless, drunks etc. In his writings, the residents, for fear of the unknown and in an attempt to protect themselves, produced private spaces that restricted communicability with the public space.

Along this line of thought, in 1972, Oscar Newman introduced the concept of "defensible space", the meaning of which corresponds to the need to develop a sense of territoriality so that users feel responsible for it, while inhibiting the presence of those considered "undesirable". Thus, Newman (1972) defended the need for a hierarchy in the city, dividing it into public space, semi-public space, semi-private space and private space. In this concept there is no segregation of flows and uses, but rather a recognition of the different types of spaces so that users feel they belong and promote informal surveillance.

Newman's (1972) debate influenced other approaches by advancing in the original sense of the "eyes on the street" concept. One of these influences resulted in the studies on Crime Prevention Through Environmental Design, in the early 1990s, and Jan Gehl's Cities for People (2010). Although these were international concepts, the approaches explain some phenomena that occur in urban design and in the domestic space, destined for social housing - formal or informal -, especially: (1) the production of blind walls or railings; and (2) postponing the completion of the walls or sidewalks.

More recently, Coelho (2012) analyzed the relationship between the domestic and the public, focusing on the essential connections between buildings and the outer space, and proposing characteristics and actions inherent to the scope of transition, which either condition or contribute to establishing and/or strengthening the connections. In his studies he addressed the physical reality from the neighborhood through to the residential buildings, in which the different spatial scales, including the relationships between them, were considered as realization levels of dwelling. Spatial levels start from the character of domestic spaces within the neighborhood. One of the relevant levels of quality for this article is the (inter)related "dwelling", which indicates the relationships between the different areas as a qualifying element for housing.

With this understanding, Coelho and Pedro (2013) considered the transition between residential buildings and the surrounding area to be a spatial sphere, in addition to being relational, referring to contiguous exteriors that welcome specific uses for the residential building. They may be private spaces of housing units, common areas of condominiums or public spaces connected to buildings. Given the importance of cohesion between residential buildings and the immediate surroundings, the authors characterized this area as a public "interior". They emphasized that attributing character to this link provides spatial diversity and contributes to the urban dynamics. Thus, within these spaces, aspects of accessibility, pleasantness and leisure may be established. These are points of attention for residents regarding spatial and functional attributes - a sequence of approaching the residential buildings - and details of specific arrangements: entrance covering, type of pavement, signage and identification structures.

For Coelho (2012) the configuration of the relationship between spaces, environments or spatial scales may be approached from two perspectives: accessibility and communicability. Accessibility in the relationship between buildings and the immediate surroundings involves facilitating approximation or establishing continuities. Important issues are safety, providing conditions for the frequent use of the external public areas, providing structures for access and efficient routes and for the sequence between public and private accessibility. Communicability, whether by physical or visual contact, establishes a correspondence between the spaces, making it possible to incorporate representative aspects of contiguous or nearby environments. It is important to highlight that, unlike these reflections, studies and theories often guide or analyze housing solutions through an approach addressing the internal and external areas of housing as being independent contexts.

It may be observed that in the formal production of $\mathrm{SH}$, as in irregular occupations, the realization of dwelling has become compromised due to the manner in which residents have closed themselves inside their homes, thereby hindering the connection between the home and the immediate 
surroundings, and restricting accessibility and communicability between the domestic and public spheres. Compromising the spatial continuity therefore results in rupturing the connections between these experiences. In view of the impacts on the living conditions of the population that lives in a socially vulnerable situation, we sought to adopt the issues discussed above as guiding references for urban improvement actions. It is proposed therefore, to demonstrate these concepts through a case study conducted in an urban context in which hostile conditions in the public space have resulted in spontaneous interventions by residents in the domestic environment, the result of which has caused ruptures within this relationship.

\section{Urban action as an object of reflection on the relationship between the domestic and public spheres}

The above-mentioned concepts and reflections guided the steps in an urban action ${ }^{5}$, adopted by implementing the instrument Technical Assistance in Social Housing - ATHIS, and conducted in an area of social vulnerability and irregular occupation in the Federal District, and corresponded to a square located in Block 3, Complexes 10 and 11, in the Northern Sector of Cidade Estrutural. This area is an urban fraction dominated by residential land use, with the provision of public and community facilities (Figure 1). The square is formed by residential lots facing onto it, with public ways circulating the living space with poor infrastructure (Figure 2). It may be observed that the frontal limits of most of the lots are closed in with walls thereby placing a limit on the relationship between the domestic and the public spheres. Conditions of public security are characterized by considerable hostility.

The urban action was guided by the understanding that dwelling transcends the housing space. It consisted of participatory planning and the execution of improvements in public spaces that contributed to alleviating the socially vulnerable condition of the population, based on the understanding of the right to the city as access to housing and to qualifying the place into which it is inserted. In line with strategies that promote community emancipation, partnership processes between the community, the government, universities and professional associations were developed and implemented with a view to qualifying the living conditions of families.

These partnerships favored the inclusion of proposals for interventions in the interface elements between the domestic and public spheres of the homes. Motivated by the participatory process, visits were carried out to the interior of the buildings, during which, the identified characteristics of the homes and their relationship with the public space were, chiefly: (1) precarious materials used in the buildings, many of which had no rendering; (2) a lack of paving in the transitional spaces between the sidewalk and the main rooms of the building; (3) outside walls constructed with no openings other than the entrance gate in closed panels. It was evident that, in most homes, residents prioritized the completion of rooms such as the kitchen, bedrooms and living room, and delayed giving any care towards balconies, facades, outer walls and sidewalks.

Figure 1: Location of the Square (action area, marked in green) in the urban fraction in 2018, signaling the main surrounding characteristics.

\footnotetext{
${ }^{5}$ The urban action was conducted by means of a participatory process within the scope of the III Conference of Technical Assistance for Social Housing - JATHIS, in 2019. The aim of JATHIS is to train students and professionals to work on themes related to the right to the city and decent housing.
} 


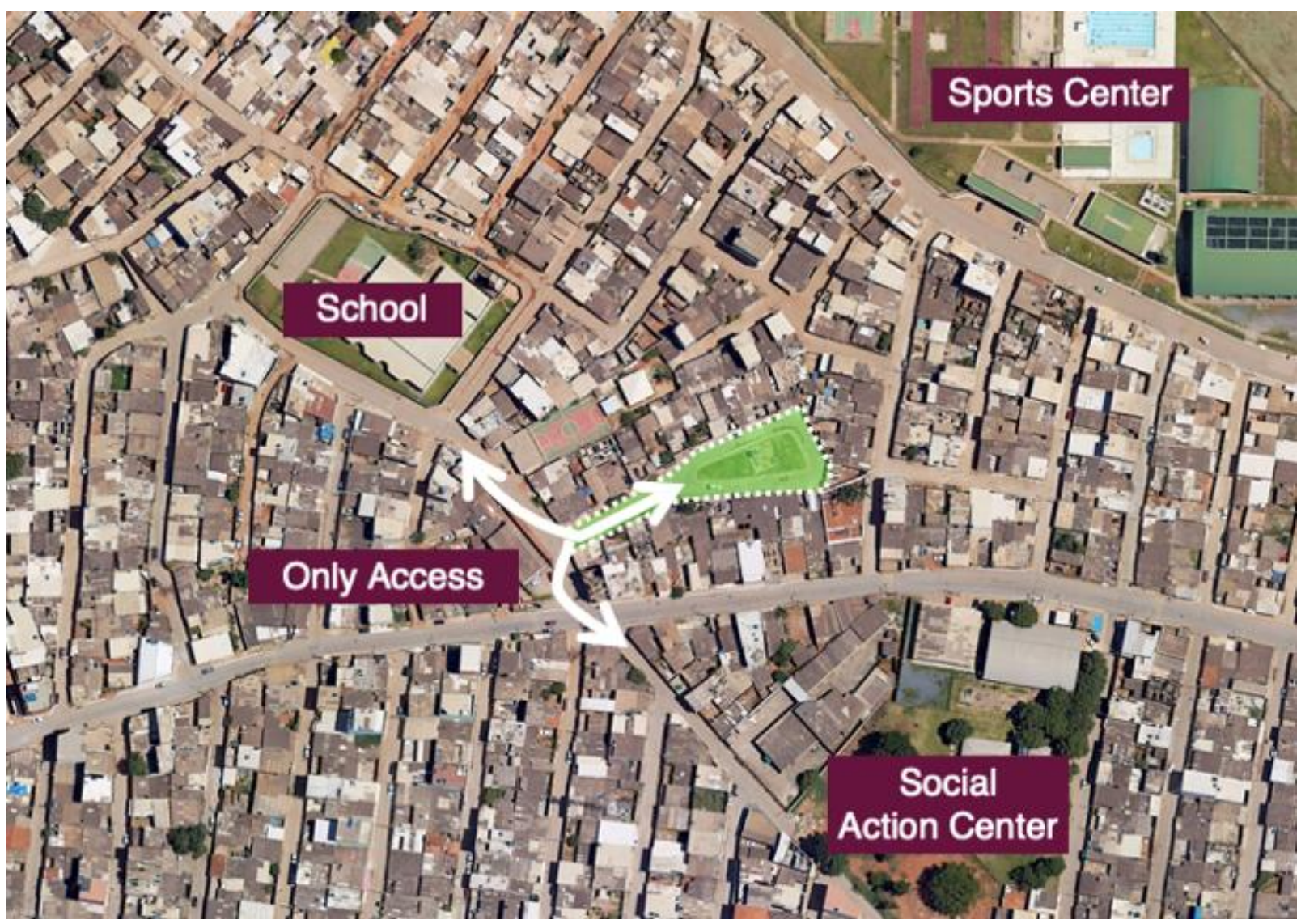

Source: Produced by the authors (2020) based on images from Google Earth 2018.

Figure 2: General View of Square (Action area)

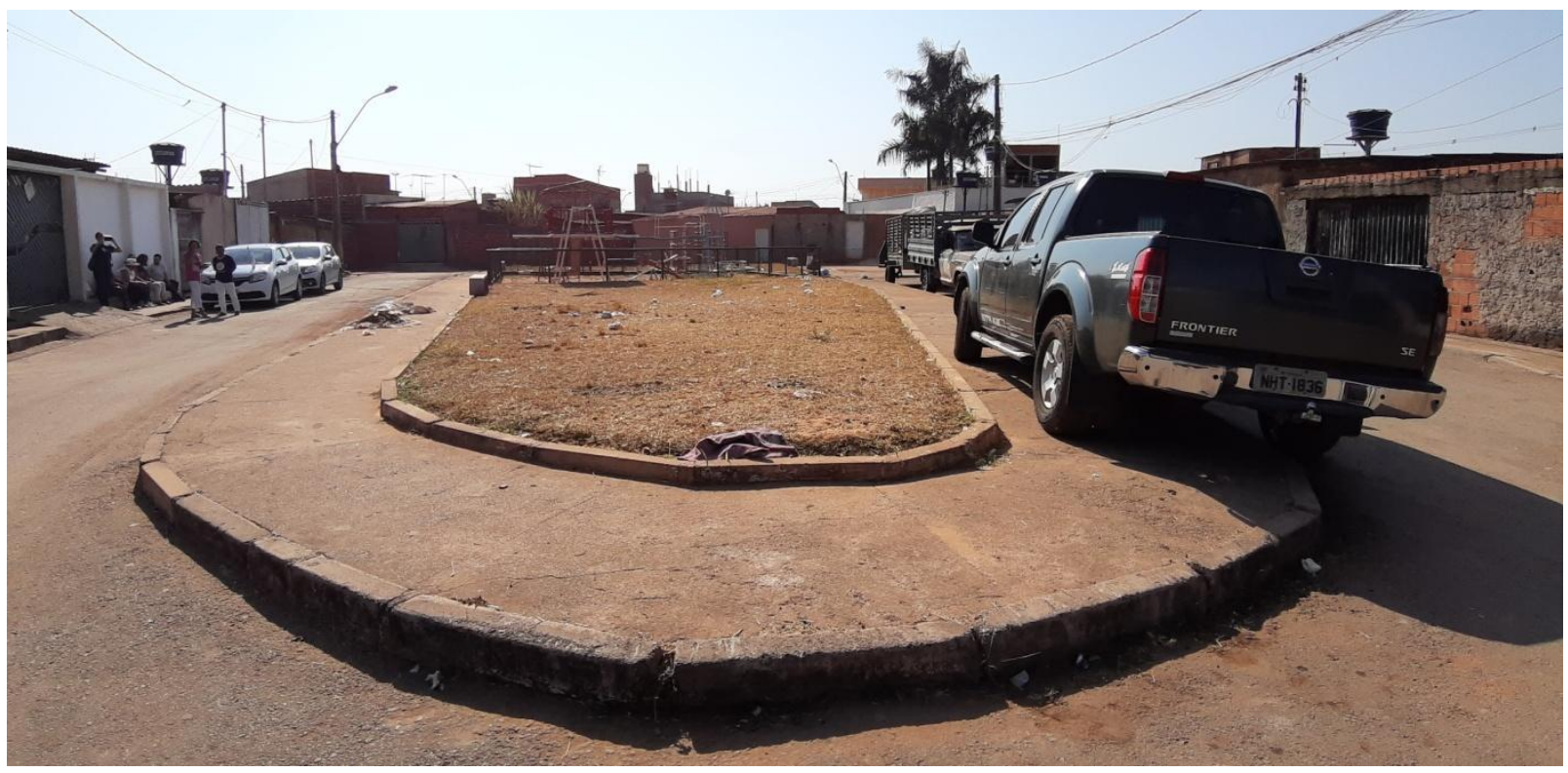

Source: JATHIS (2019).

The visits were mainly focused on understanding how the participatory project could promote links between the domestic and public spheres. In other words, the interest was guided towards understanding the (inter)related "dwelling" par excellence. As a starting point, conversations were initiated on the possibility of installing panels along the outside walls. These conversations led to other basic points of this relationship, especially linked to outside walls, openings and the use of sidewalks.

The outside walls were established as the only element of separation between the domestic 
environments and the outside space. Many of the buildings are aligned to within the full extent of the lot, since the dimensions are insufficient for cohabiting ${ }^{6}$ families. This does not signify however that these outside walls are the façades of the buildings, since their design and constructive structure is that of outside walls.

The sidewalks are irregularly paved, some with ramps for vehicle access and others in an advanced state of deterioration. Both conditions restrict the ability for pedestrian traffic to flow more smoothly, causing pedestrians to circulate in the roadway, along with the motor vehicles or in the central square. Furthermore, cars were often found parked on the sidewalks. Daily social practice leads to the belief that there is a preference for residents to use the roadway as the main channel for moving around.

This initial reading regarding the material conditions and social practices that take place in the observed area enabled us to extract some considerations from the theorization established in the previous section. Two perspectives were selected on which to focus, and were the same as those presented by Coelho (2012): accessibility and communicability.

Accessibility is a condition for the frequent, intense use of the public sphere. It is essentially urban, although it has advantages when it infiltrates the thresholds between the domestic and public spheres. For this perspective, the sidewalk makes an important contribution, since it is the main accessibility mechanism at this threshold. The sidewalk is the first contact that residents have with the public space.

Due to Brazilian laws, the sidewalk is in the public domain, and responsibility for maintaining it falls to the owner of the lot immediately in front. This characteristic establishes ambiguity between what is public and private, generating different positions depending on each individual resident. Owners, who need to use the sidewalk in order to be able to access the lot, also build the ramps. Others, due to the unavailability of space inside the lot, use it for storage. Owners whose interior domestic environmental comfort has been prejudiced install benches and other temporary furniture there. These are aspects of the daily dynamics, which demonstrate that the relationship between the domestic and public spheres is in fact more flexible than the rigid signs of the outside walls.

With the exception of installing temporary furniture, the sidewalks are not placed at the service of the residents in order to remain in the public space. The square lacks any kind of pleasant attribute. Indeed, throughout the participatory process, some of the residents verified the need to introduce plants and other enhancing decorative features. These two conditions - namely, furniture and a lack of pleasantness - emphasized the conditions of hostility and low attractiveness. Interestingly, at the same time that there is a desire to implement improvements in these transitional spaces between the domestic and the public, reaction to the fear of the "undesirable" implies the creation of elements of hostility towards the outside public. Invariably, these elements also create difficulties in permanence, since they limit accessibility.

Based on the assumption that the population uses public spaces sequentially - first the sidewalk, then the street, the square, the bus stop, etc. - it is necessary that the entire system of free spaces should be more functional, pleasant and strategic, in relation to the routes. Thus, it may be seen that the elements of hostility around the square reverberate over the entire system of accessibility from the domestic interior through to public transport points.

On individual contact with the residents, the main aspect regarding the pleasantness of the space was the possibility of implementing panels along the outside walls. This proposal was designed as a way of expressing the individuality of each family, as well as being a powerful manner with which to enhance the background of the square. Amongst the 23 houses surrounding the square, 4 families chose not to have the panels, justifying their lack of involvement in the proposed action as being due to conflicts with other residents. The expression of individuality enabled the active involvement of the residents initially by painting the walls, and later with the transformation of the square. In general, after the painting had been completed, the residents demonstrated their satisfaction with the panels verbally, justifying that they had been without the necessary resources to complete the walls, but felt satisfaction in being able to make their homes more beautiful, since it was an important space for the family to communicate with the urban context. The approach on accessibility evidenced a series of conflicts along the lines of appropriating the square, and was therefore cause for a deeper investigation.

Concern with the quantitative and qualitative accessibility of space is a recurring theme in the literature

${ }^{6}$ Cohabitation is understood as the condition in which two or more families live in the same house. 
and is historically relevant. The modernist principles of the functionalist city emphasized and proposed efficient cities, for which domestic-public accessibility reinforced the sense of "a machine for living in". The space of the square, the object of investigation, was configured in opposition to these principles, since it is the result of the conflicting tensions in the production of space. The site is the result of spontaneous, informal occupation and, although it has been the object of state regularization, its legacy is a history of social actions especially linked to the original occupants. In the beginning, according to resident reports, the original land was of an irregular geometry and was occupied according to the interests of family members. Over the decades, the lots have been subdivided and assigned or sold, thereby diversifying the social actors. It is evident that this expansion of agents has also represented a diversification of interests towards the public space. Sometimes, these interests are antagonistic and have resulted in disputes. For this reason, it is not possible to read this space as the result of an efficient, rigid accessibility, since it originates from this historical process of the production of space.

Further clear evidence of this process of negotiating the occupation of space is in residential architectural communicability. This concept may be defined as that which is connected or that has physical or visual contact, being, therefore, the connection between contiguous or nearby environments. The communicability approach was present in the discussions throughout the process, and was recognized by the population as an important element.

A first approach took place during the community meetings, where it was possible to highlight the importance of communicability between the interior of the homes and the square. At this moment, the debate on Jacobs' "eyes on the street" of 1961 was taken up, from the moment when the advantages of the openings were presented in promoting urban vitality and strengthening (inter)related "dwelling". Subsequent debates originating from Jacobs were also raised (NEWMAN, 1972; WHYTE, 1968), especially in the capacity of these openings in promoting social control and extending a sense of security in view of the fear of "undesirable" individuals - as defined by Whyte (1968).

Individual meetings with each family made it possible to broaden the debate on communicability. At this moment, the clarity of the residents was made evident regarding the importance of having openings in the walls facing onto the square, and at the same time, a lack of understanding on how each wall could contribute to the public space. The tool of design (see Figure $3^{7}$ ) made it possible to explore and resolve this lack of understanding, as it illustrated the advantages of the openings (windows, doors, gaps between buildings, etc.), demonstrating that there is a reciprocal contribution to transparency between the two spaces. The most common arguments regarding this reciprocity were: (1) the possibility of natural ventilation; (2) the harmonious composition of the wall design; and (3) expanding the capacity of the street and square surveillance.

It is known that transparency mediated by constructive elements has the ability to partially reveal residential contents and from there characterize a neighborhood. Thus, based on this characterization, it is possible to enrich the identity and character of the territory, making it possible to transport this identity from the outside through into the domestic space. Hence the importance emerged of a more attentive analysis to the possibilities of communicability, in order to identify the potential relationship between the domestic and public spheres.

Figure 3: The process of implementing the wall panels.

\footnotetext{
7 During the conversation with residents, several sketches were drawn up to identify their wishes. The representations expressed the individuality of each family. In the example in Figure 3, the religiosity of the matriarch was represented. Changes in the original design were made during the entire process, from listening to the wishes of the receiving family, who also assisted in the execution of the panel.
} 

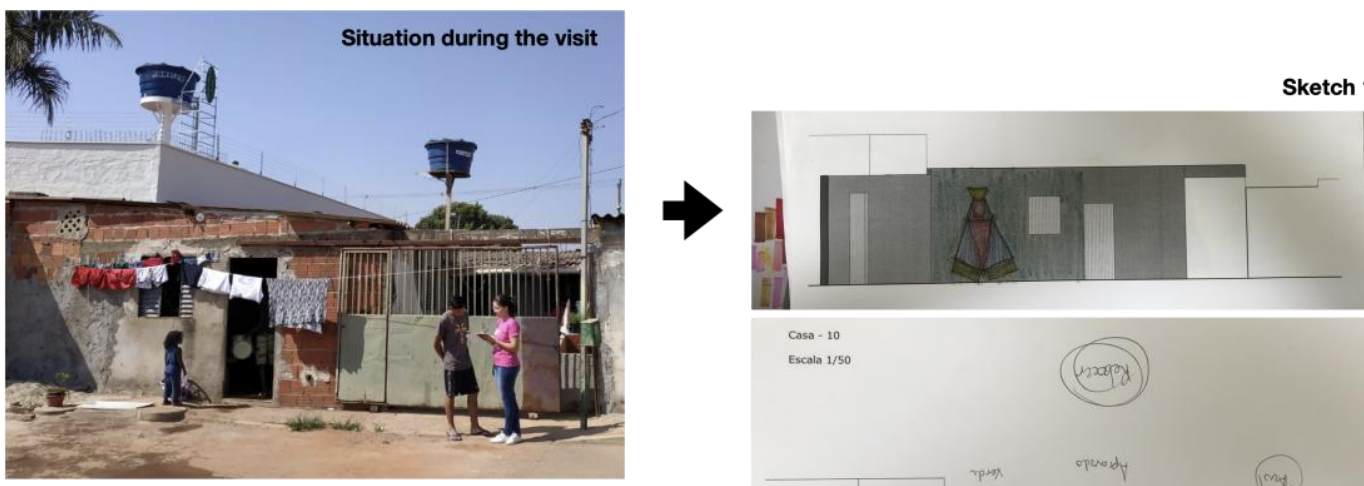

Sketch 2
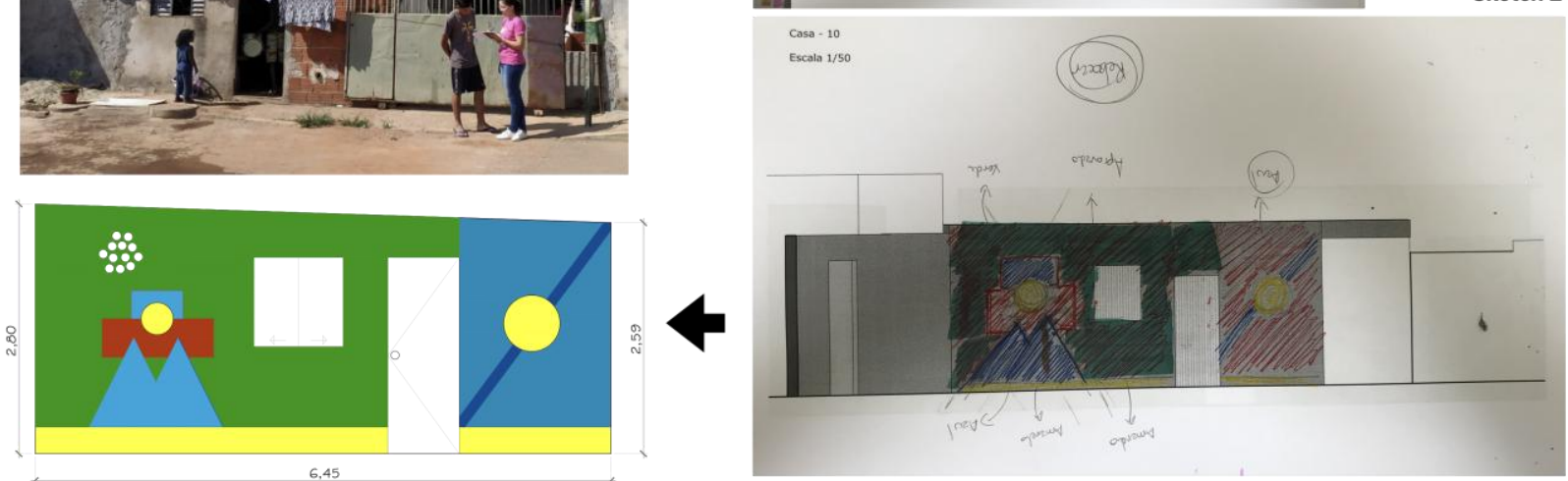

Technical project
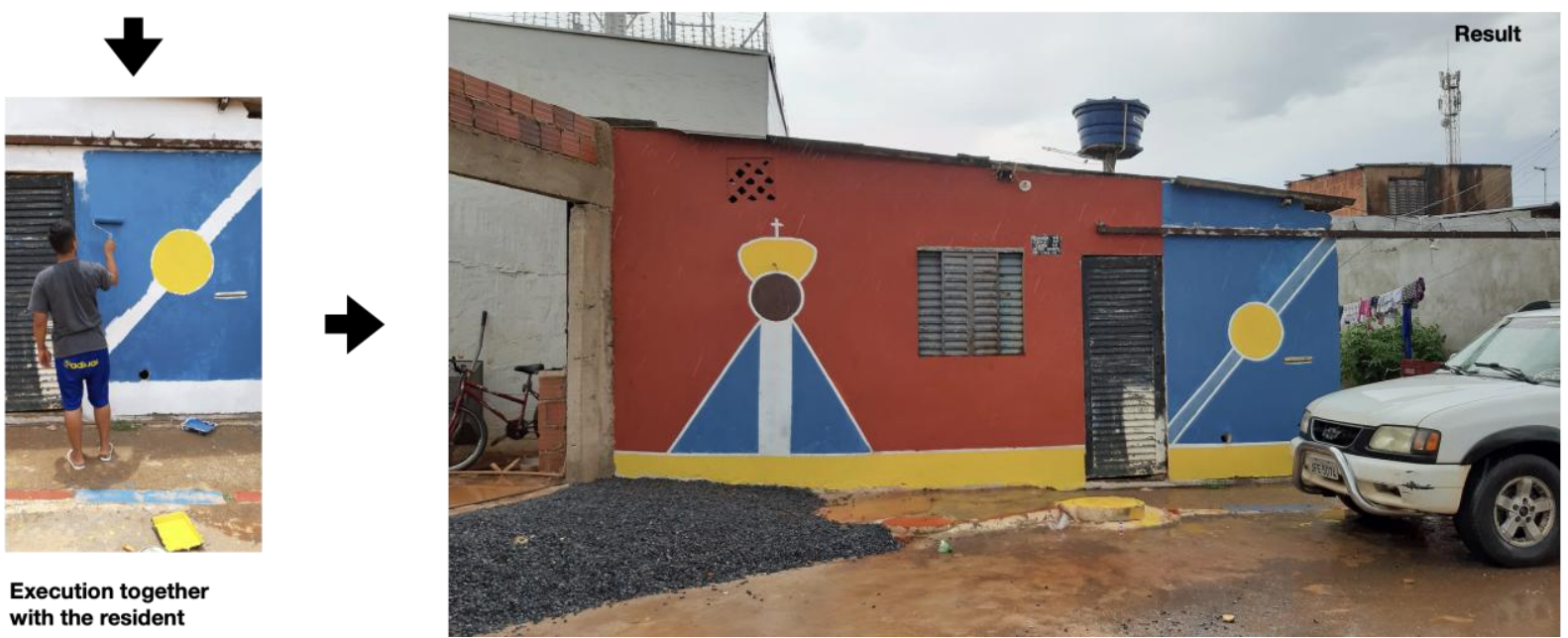

Execution togethe with the resident

Source: Produced by the authors from the JATHIS collection (2019).

In the case of the square, it was observed that the few existing openings had been introduced in the front gates, either in order to access the padlocks on the inside or as a stylistic feature. Some of the gates, during more transparent times, had been changed with metal plates so as to obstruct the view, due to the culture of fear when faced with violence. Or, in specific cases, it was observed that expanding the house resulted in incorporating the front section of the lot with an essential part of the building (transforming it into a living room or kitchen) and, therefore, for privacy reasons, sections had been installed so as to block the view from the outside to the inside.

Once again, the history of social housing in Brazil is clear, shaping the relationship between the domestic and public spheres, i.e., the housing deficit has brought about changes in the manner of occupying urban plots, with cohabitation and excessive density. In terms of family composition, children or other relatives have installed themselves in the house after it has been established, either to make savings or to join incomes. This cohabitation has required homes to be constantly extended, often out to the back, side and front limits of the lot. Upon reaching the front limits, the gate has become the main entrance of the home. The photographs (Figure 4) below present a gate with a building set back and openings (left), as well as another house (right) excessively dense, whose construction has reached the front limit of the lot, creating an additional bedroom and the main living room, which implied closing the openings.

Figure 4: A wall as an interface element between the domestic and public spheres. Buildings set back (left) and aligned to the limit of the lot (right). 

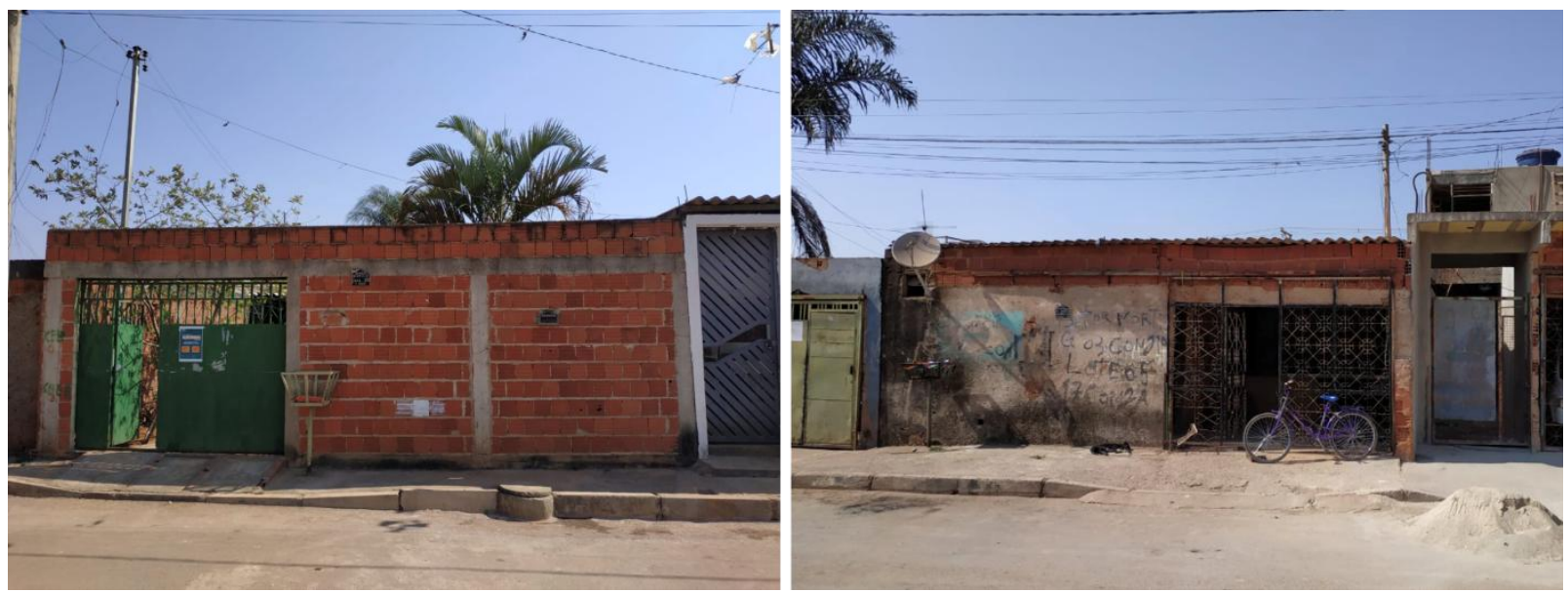

Source: JATHIS, 2019

In cases where the domestic space was located right at the front of the lot and where greater privacy was required (for example, the bedroom), conversations concerning the possibility of openings were quickly rejected by residents. In lots where the frontage spaces demand less privacy, the proposals were accepted and planned in a design (see facade design, whose interior was a balcony used as a room, in Figure 5). In all cases where the building was set back from the front limits of the lot, residents recognized the reciprocity of the benefits when having an opening in the wall to establish conditions of communicability (Figure 6).

Figure 5: Improvement studies for the front walls of homes, including openings, showing the acceptance of "communicability".

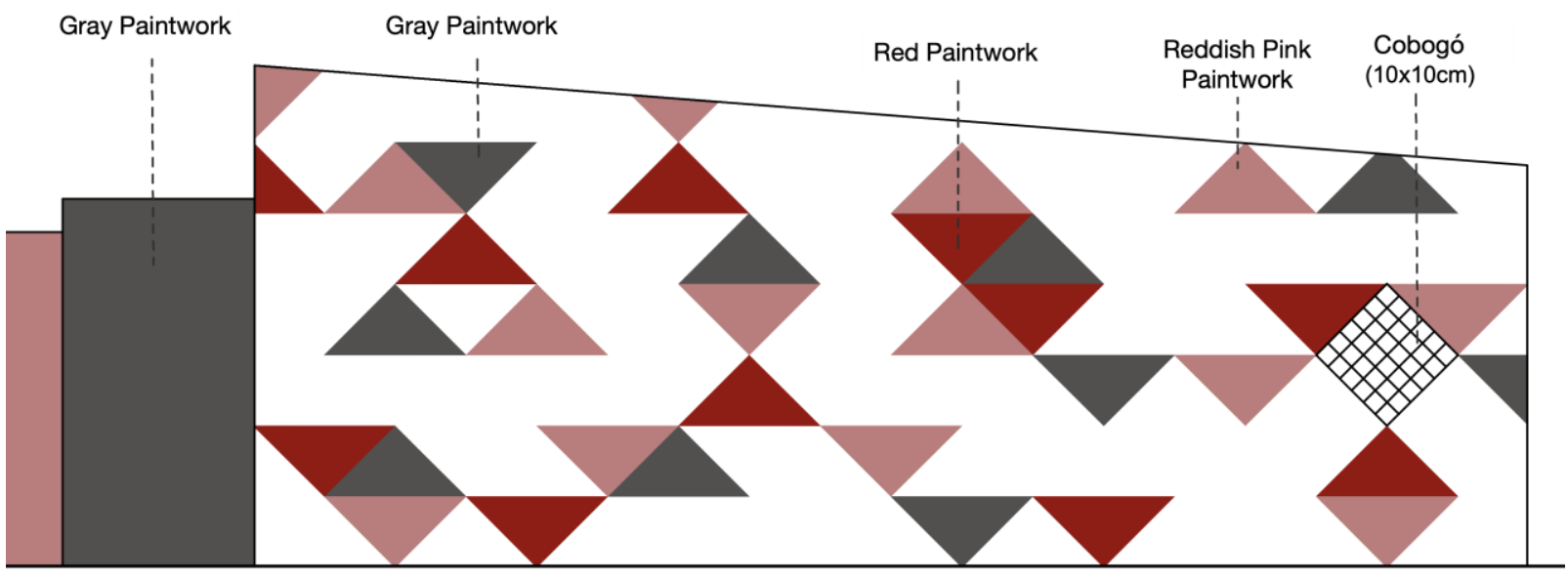

Source: JATHIS, 2019 
Figure 6: Wall panel design, highlighting the opening with cobogós ${ }^{8}$ at eye level in the part where the building is set back from the front limits of the lot.

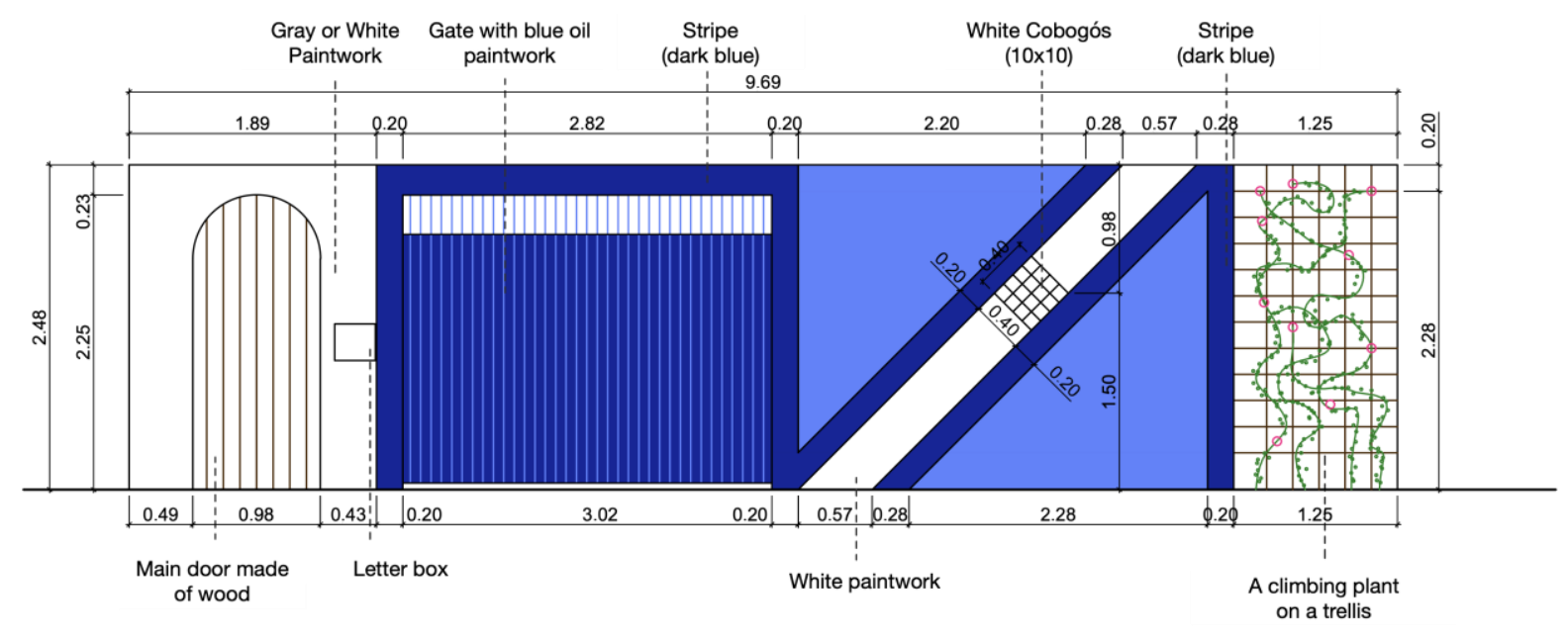

Source: JATHIS (2019). Measurements in meters.

In view of the actions and reflections conducted during the urban action, it is important to highlight that the approach to the work area enabled an initial recognition of the families' life dynamics and the use/appropriation of the public space. It was observed that there was a limited link between the local community, expressive signs of conflicts in interpersonal relationships, conditions of insecurity resulting from drug trafficking, which resulted in the low use of public space. Through meetings with the community, it was possible to indicate the potential for qualifying the urban environment through activities so that people could remain there and circulate, highlighting that the daily dynamics in the public space contributes to urban security and to strengthening the sense of community. The necessary connections between the domestic and public spheres were emphasized, highlighting the positive contributions to daily life related to their integration, based on the presence of "eyes on the street" and undertaking experiences in the public space, which were complements to domestic life, and were able to promote accessibility and communicability.

\section{Conclusion}

The historical course of social housing in Brazil has presented efforts to provide decent housing for the population living in a situation of social vulnerability. Institutional actions were prominent at specific moments, particularly during the periods of Estado Novo, the activities of BNH and, in recent years, with the implementation of the Minha Casa, Minha Vida [My Home, My Life] Program". In parallel with government action, the unattended population has pursued its own housing solution within the scope of informality. In view of this complexity, this article has sought to highlight the recurrently compromised daily life for these families, irrespective of the forms of access to housing.

Through understanding the concept of "dwelling" and its realization in different spatial areas, we have sought to understand the connections between the domestic and public spheres, as well as the strategies for its consolidation. Approaching concepts established in the literature and applying them to a case study has enabled us to verify that even in a context of urban hostility and aggressiveness, the desire is nonetheless manifested for public life, and the opportunity of the participatory process undertaken resulted in accepting and proposing transformative interventions in the established dynamics.

It was observed that the conformation of the urban fraction and the interior of the lots is the result of a historical process, conditioned by social macro-structures that are beyond the control of the residents. The form of occupation reflects their way of life, which changes over time, demonstrating that the relationship between the domestic and public spheres permeates the understanding of the historical process of how the dwelling space has been formed. There are aspects inherent to everyday urban life

\footnotetext{
${ }^{8}$ Cobogó is a hollow block that is filled with empty spaces, to replace bricks and provide ventilation, lighting and transparency. They come in different shapes and may be prefabricated.
} 
that determine the positions of each resident in relation to the public space. In the case of the study area, the result was the compromised (inter)related "dwelling".

However, the participatory process promoted reflections and a review of attitudes, which then became consolidated through the interventions on the outer walls of the residences, thereby enabling the reestablishment of communicability and accessibility on this threshold. "Eyes on the street" was established, consolidating the natural surveillance towards the public space. Equally expressive was the appropriation of the sidewalks as a living space, emphasizing the transition and continuity with the interior of the lots and promoting a hierarchical flow between public space, semi-public space, semiprivate space and private space. Thus, the sequence between public and private accessibility was addressed by aspects of pleasantness and leisure. The conditions of use of the public exterior were favored by consolidating access structures and routes. There is a complementary understanding that with the users recognizing the different types of spaces, this will enable their appropriation and the consequent feeling of belonging.

In addition to the physical elements inherent to the interventions undertaken, the appropriation of the symbolic aspects of "dwelling" was also observed. The proposals for the openings and illustrations created in conjunction with each family, were configured as a manifestation of individualities, establishing the attribution of character to the domestic-public linkage. The interior-exterior relationship changed from a context in which families were isolated from the public space to a condition in which they related to it through individual expressions. These were transformations that contributed to strengthening connections, bringing about the fundamental continuity between the domestic and public spheres. In a continuous process, these newly established connections will bring about an increase of experiences in the urban space, contributing to a reduction in the hostility and aggressiveness observed at the time, which may be the object of future investigations. The continuous acceptance of the daily dynamics within these spaces will consolidate favorable living conditions for the residents.

\section{References}

BONDUKI, N. G.; KOURY, A. P. Os pioneiros da habitação social: Cem anos de política pública no Brasil. 1a ed. São Paulo: Edições SESC, 2014. v. 1.

BONDUKI, N. Origens da habitação social no Brasil. Análise Social, Lisboa, v. 3, n. 127, p. 711-732, abr. 1994.

. Origens da habitação social no Brasil: arquitetura moderna, lei do inquilinato e difusão da casa própria. São Paulo: Fapesp, 1998.

BLUMENSCHEIN, R. N.; PEIXOTO, E. R.; GUINANCIO, C. Avaliação da qualidade da habitação de interesse social: projetos urbanístico e arquitetônico e qualidade construtiva. Brasília: UnB/FAU, 2015.

CIANCIOTTO, L M. Public Space, Common Space, and the Spaces In-Between: a case study of philadelphia's love park. City \& Community, v. 19, n. 3, p. 676-703, set. 2020.

COELHO, A. B. Habitação e Arquitetura: Contributos para um habitar e um espaço urbano com mais qualidade. Lisboa: Laboratório Nacional de Engenharia Civil, I. P., 2012.

COELHO, A. B.; PEDRO, J. B. Do bairro e da vizinhança à habitação: tipologias e caracterização dos níveis físicos residenciais. Lisboa: LNEC, 2013.

CORREA, J. D. A. Em torno da dinâmica espaço-tempo. In: LEITÃO, L.; AMORIM, L. A casa nossa de cada dia. Recife: Ed. UFPE, 2007. p. 23-46.

CORREIA, T. D. B. A construção do habitat moderno no Brasil: 1870-1950. São Paulo: RiMa, 2004.

DE PAOLI, D. O valor do desenho urbano na construção de bairros habitacionais e comunidades. 2014. 251 p. Tese (doutorado) - Universidade Estadual de Campinas, Faculdade de Engenharia Civil, Arquitetura e Urbanismo, Campinas, SP. 2014. 
DEMO, P. Metodologia científica em Ciências Sociais. São Paulo: Atlas, 1995.

FURLAN, D. L. S.; DUDA, M. E. Estado da arte da pesquisa científica sobre ATHIS. In: ENCONTRO NACIONAL DA ASSOCIAÇÃO NACIONAL DE PÓS-GRADUAÇÃO E PESQUISA EM PLANEJAMENTO URBANO E REGIONAL, 18., 2019, Natal. Anais... Natal: ANPUR, 2019. p. 1-24.

GEHL, J. Cities for people. Washington, D.C.: Island Press, 2010.

GORI, R. M. de A. Observação Participativa e Pesquisa-Ação: Aplicações. Itinerarius Reflectionis, v. 1, n. 2, p. 113-120, jan./jun. 2006.

IBGE. Estatísticas de Gênero. 2020. Available at: <https://www.ibge.gov.br/apps/snig/v1/ notas_metodologicas.html?loc=0 $>$. Viewed on: July 30, 2020.

JACOBS, J. The Death and Life of Great American Cities. New York: Random House, 1961.

JACQUES, P. B. Breve histórico da Internacional Situacionista - IS. Arquitextos, São Paulo, ano 03, n. 035.05, Vitruvius, abr. 2003. Disponível em: <https://www.vitruvius.com.br/revistas/read/ arquitextos/03.035/696>. Acesso em: 29 jul. 2020.

MÜLLER, M.; TRUBINA, E. Improvising urban spaces, inhabiting the in-between. Environment and Planning D: Society and Space, v. 38, n. 4, p. 664-681, maio 2020.

NEWMAN, O. Creating defensible space. Washington, D.C.: U.S. Department of Housing and Urban Development Office of Policy Development and Research, 1996.

Defensible space: People and Design in the Violent City. New York: Macmillan, 1972.

OLIVEIRA, F. Crítica à razão dualista/O ornitorrinco. São Paulo: Boitempo editorial, 2015.

PEREIRA, S. M. Casa e mudança social: uma leitura das transformações da sociedade portuguesa a partir da casa. Lisboa: Caleidoscópio, 2012.

REIS CABRITA, A. M. O homem e a casa: definição individual e social da qualidade da habitação. Lisboa: LNEC, 1995.

SILVA, A. R. P. "LIMEN"- a soleira: estudo do espaço de transição interior/exterior da habitação: relações sociais e identidade. 2012. 124 f. Dissertação (Mestrado em Arquitetura) - Faculdade de Arquitetura, Universidade Técnica de Lisboa, Lisboa, 2012.

SUN, K.; PONT, M. B.; LEGEBY, A. Squares for co-presence: The influence of urban form on the intensity and diversity of people co-present in 12 squares in Gothenburg. In: INTERNATIONAL SPACE SYNTAX SYMPOSIUM, 11., 2017, Lisboa. Anais... Lisboa: SSS Lisbon, 2017. p. 115.1-115.20.

THIOLLENT, M. Metodologia da pesquisa-ação. São Paulo: Cortez, 2000.

TOPRAK, I.; ÜNL, A.; NES, A. V. Street networks as places of social interaction in culturally diverse neighbourhoods of Istanbul. In: INTERNATIONAL SPACE SYNTAX SYMPOSIUM, 12., 2019, Beijing. Anais eletrônicos... Beijing: SSS Beijing, 2019, p. 170.1-170.19.

WENDT, M. The importance of Death and Life of Great American Cities (1961) by Jane Jacobs to the Profession of Urban Planning. Newark: New Visions for Public Affairs, School of Urban Affairs and Public Policy - University of Delaware, 2009. v. 1.

WHYTE, W. H. The last landscape. New York: Doubleday, 1968.

ZEROUATI, W.; BELLAL, T. Evaluating the impact of mass housings' in-between spaces' spatial configuration on users' social interaction. Frontiers of Architectural Research, v. 9, n. 1, p. 34-53, mar. 2020. 